AUTHOR:

Barend van der Walt

AFFILIATION:

Skool vir Filosofie,

Potchefstroomkampus, Noordwes-

Universiteit, Potchefstroom

CORRESPONDENCE TO:

Barend van der Walt

POSTAL ADDRESS:

Private Bag X6001, Potchefstroom Campus, North-West University, Potchefstroom, 2520, South Africa

DATES:

Published: 21 Aug 2018

HOW TO CITE THIS ARTICLE:

van der Walt, B.J., 2018. 'n Kykie na Kopstukke. Filosofie op Potchefstroom die afgelope eeu (1917-2017), Deel 2 : die sisteembouers. KOERS - Bulletin for Christian Scholarship, 83(1).

Available at: https://doi.org/10.19108/ KOERS.83.1.2371

COPYRIGHT:

(C) 2018. The Author(s).

Published under the Creative Commons Attribution License.

\section{'n Kykie na Kopstukke Filosofie op Potchefstroom die afgelope eeu (1917-2017), Deel 2: die sisteembouers}

\section{ABSTRACT \\ A peephole on big guns; philosophy at Potchefstroom during the past century (1917-2017). Part 2: the systematic philosophers}

\begin{abstract}
While during the last century philosophy played a key-role in shaping the Christian character of the erstwhile Potchefstroom University for Christian Higher Education (now a campus of the North-West University), its history has not yet been documented and published. In a series of four articles the author provides a preliminary reconnaissance and outline to fill this lacuna and to encourage possible further research.
\end{abstract}

\begin{abstract}
A previous article in this journal investigated the philosophers, F. Postma and S.O. LoS, and the nature of the philosophies they taught about a hundred years ago (1916) at the Potchefstroom University College (cf. Van der Walt 2017). This first period may be characterised as a time of philosophical reconnoitring. The following hundred years (of about 1916 to 2017) of philosophy can be divided into three main phases: first a time of system-building, followed by a period of philosophical elaboration and finally of reconsideration. This review deals with the second period of system-building (Stoker \& Taljaard) while the next will discuss the third period of elaboration (the following philosophers) while the third will review the present critical situation. As the title of the first two contributions suggests, the writer acts as a fly on the wall looking back at the "big guns", those philosophers who headed the Department (later School) of Philosophy at Potchefstroom, to indicate inter alia what their academic backgrounds, fields of specialisation and publications were.
\end{abstract}

Since all of them shared a commitment to a Christian approach in their philosophising the essay in conclusion focuses on the deepest religious foundations of their thinking. The third article will provide a more detailed critical evaluation of the possible impact of the Christian Reformational philosophical tradition in philosophy at Potchefstroom.

\section{KEY CONCEPTS}

Subjects: Christian-reformational Philosophy, North-West University, Potchefstroom University for CHE, Free University (Amsterdam), Theology.

Philosophers: Stoker, H.G. (1899-1993), Taljaard, J.A.L. (1915-1994).

\section{SAMEVATTING}

Die vak Wysbegeerte (later herdoop tot Filosofie) se handvol filosowe het vir die grootste deel van die afgelope eeu belangrike bydraes gelewer in die bepaling van die Christelike karakter van die Potchefstroomse Universiteit vir Christelike Hoër Onderwys

Behalwe min of meer terloopse verwysings na die vak of persone wat dit aangebied het in algemene geskiedenisse van die PUK, is daar egter nog niks oor die geskiedenis van filosofie en die kopstukke daarby betrokke te boek gestel nie. Met enkele hooflyne wil hierdie verkenning in dié leemte voorsien en verdere detailnavorsing stimuleer.

In h vorige bydrae (Van der Walt, 2017) is die tydperk van wysgerige verkenning tot ongeveer 1916 met figure soos proff. S. O. Los en F. Postma bekyk. Hierdie bydrae fokus op die bydraes 
van twee figure gedurende die tweede periode van sistematisering van hi Christelike filosofie, Hendrik Gerhardus Stoker (dosent aan die begin van die twintigerjare en vanaf 1936 tot 1964 departementshoof) en Jan Adrian Louw Taljaard (dosent vanaf 1948 en departementshoof vanaf 1965 tot 1974). Wat het hulle akademiese opleiding behels, wat was hulle besondere belangstellings en publikasies? Die artikel word afges/uit met h terugblik op die gemeenskaplike religieuse grondslae van hulle denke.

In h volgende (derde) aflewering sal daaropvolgende, latere filosofiese kopstukke bekyk word, verteenwoordigers van in derde periode in die geskiedenis van filosofie op Potchefstroom, naamlik wysgerige uitbouing. Die reeks sal afgesluit word met hi vierde en laaste bylae oor die meer resente situasie vanaf ongeveer 2010.

\section{TREFWOORDE}

Onderwerpe: Christelik-reformatoriese Filosofie, Noordwes-Universiteit, Potchefstroomse Universiteit vir CHO, Vrije Universiteit (Amsterdam), Teologie.

Filosowe: Stoker, H.G. (1899-1993), Taljaard, J.A.L. (1915-1994).

\section{Inleidend}

Vooraf enkele noodsaaklike verduidelikings.

\subsection{Groot leemte}

Weens sy aard (grondliggendheid en omvattendheid) en rigtinggewende karakter ('n normatief-Christelike benadering) het filosofie die afgelope eeu ' $n$ belangrike rol aan die Potchefstroomse Universiteit vir Christelike Hoër Onderwys (in vervolg afgekort as PUK) gespeel. Nogtans is die geskiedenis van hierdie vak en sy dosente, behalwe vir terloopse gegewens in algemene geskiedenisse van die PUK (bv. Van der Schyff, 2003 en Van Eeden, 2005) nog nie geskryf nie. Ook in Duvenage (2015:197) word die Potchefstroomse filosofie net in die verbygaan vermeld en in 'n Nederlandse publikasie word nie eers ' $n$ volle bladsy daaraan gewy nie (Hengstmengel, 2015:134).

Is dit die manier waarop 'n nageslag aan hulle voorgangers dankbaarheid vir pionierwerk toon? Stoker se lewe bied byvoorbeeld genoeg stof vir 'n interessante biografie. Waarom bestaan dit nog nie?

\subsubsection{Die Nederlandse voorbeeld}

In die geval van filosofie aan die Vrije Universiteit (VU) in Amsterdam, Nederland het alreeds talle publikasies die verlede in herinnering geroep.

By die 25-jarige herdenking van die Vereniging voor Calvinistische Wijsbegeerte het die jongere garde reeds in erkenning aan ses kopstukke van die reformatoriese filosofie in Nederland 'n feesbundel uitgegee (Van Dijk \& Stellingwerff, 1961). Daarna bied Zijlstra (in Kalsbeek, 1975:14-33) in Engels sy eie oorsig en evaluering van hierdie tradisie. Klapwijk (1980:528-493) volg dit later op met 'n uitgebreide en indringend-kritiese evaluering van die bydraes van reformatoriese filosowe aan die VU vanaf 1880 tot 1980 . Stellingwerff (2006) gee later weer 'n populêre oorsig. Meer resent is die werk van Woldring (2013), wat die hele geskiedenis van filosofie en filosowe aan die VU vanaf sy ontstaan in 1880 tot 2012 behandel. Populêre weergawes van hierdie tradisie is dié van Bartholomew en Goheen (2013) en Hengstmengel (2015).

Behalwe hierdie breë oorsigte bestaan daar ook biografieë oor bv. Vollenhoven (Stellingwerff, 1992) en Dooyeweerd (Verburg, 1989) en talle detailstudies oor verskillende fasette van hulle filosofieë - te veel om hier op te noem (bv. Tol, 2010, oor Vollenhoven) asook gedenkbundels aan hulle opgedra, bv. vir Vollenhoven (Bril e.a., 1973) en Dooyeweerd (De 
Gaay Fortman, 1965). Van hulle geskrifte is herdruk en in Engels vertaal.

Ook dit behels nog nie die volledige oes nie, want in verskillende boeke oor die geskiedenis van VU kom hierdie kopstukke weer ter sprake.

Hierdie gegewens word hier verstrek, nie net om die noodsaak van 'n eie Potchefstroomse geskiedenis te onderstreep nie, maar ook omdat daar 'n lang en nou band bestaan het tussen die wysgerige tradisie aan VU en die PUK (vgl. 1.6 hierna).

\subsubsection{Die uurglas loop leeg}

Omdat die meeste van die kopstukke wat in hierdie reeks ter sprake kom alreeds oorlede is en van die nog lewendes ook nie meer jonk is nie, loop die tyd uit om wel iets aan hierdie leemte te doen, al is dit (soos hier) om net enkele hooflyne te trek en basiese gegewens te bied met die oog op moontlike toekomstige detailnavorsing.

Hierdie bydrae volg die geskiedenis verder na die skrywer se vorige bydrae oor wat filosofie 100 jaar gelede teen 1916 behels het in die geval van figure soos F. Postma en S.O. Los (vgl. Van der Walt, 2017).

\subsubsection{Erkenning en inspirasie}

Die geskiedenis word vir twee redes hier verder opgeteken. Eerstens as'n blyk van waardering van die skrywer self op sy oudag (79) vir die besondere voorreg wat hyself geniet het om as student te kon sit aan die voete van formidabele dosente asook die jarelange kontak met latere filosofiese kopstukke. Mag, tweedens, as iemand eendag hierdie geskiedenis lees, dit vir haar/hom as inspirasie dien om meer oor 'n besondere en ryk tradisie uit te vind.

\subsection{Bronne}

Ongelukkig bevat die Argief en Museum van die NWU (op Potchefstroom) slegs losstaande gegewens oor die Departement Filosofie tussen die jare 1971 en 1992 wat bowendien uiters onvolledig is en daar in die argiefstukke soms ook nie onderskei word tussen Filosofie en byvoorbeeld die Departement Wetenskapsleer of die Instituut vir Reformatoriese Studie nie. Die hoofbronne vir hierdie reeks was die volgende: die CV's van die reeds gestorwe persone in die Argief; die CV's van die nog lewendes aan die skrywer voorsien; al die figure se publikasies in die Ferdinand Postma Biblioteek; die huldigingsbundels wat na sommiges se uittrede aan hulle opgedra is, waarvan die meeste ook in die biblioteek van die skrywer self.

Die skrywer was ook bevoorreg om persoonlik'n groot deel van die geskiedenis mee te maak - vanaf 1958 as student van Stoker, Taljaard en Du Plessis en later as studente-assistent. Nadat hy (in 1974) as Direkteur van die Instituut vir Reformatoriese Studie (IRS) benoem is, en later (1980) tot professor bevorder is, het ook hy in filosofie klas gegee, terwyl hy na sy aftrede (1999) tot op datum nog steeds as navorsingsgenoot by die Skool vir Filosofie betrokke is. Vir hierdie ondersoek kwalifiseer hy dus as 'n vlieg teen die muur van klas-, studeerkamer en kantoor.

\subsection{Beperking}

Indien die nodige materiaal nog beskikbaar was, sou verskillende fasette van die onderwys in die filosofie nagegaan kon word. Só byvoorbeeld, wat die leerplanne op verskillende tye behels het; watter handboeke daarvoor voorgeskryf is; watter studente M- en D-grade in Filosofie behaal het; hoe die breëre universiteitsbeleid Filosofie ten goede of nadelig beïnvloed het; die Departement en sy personeel se betrokkenheid in die breë SuidAfrikaanse samelewing asook internasionale kontakte. Daar was, soos reeds genoem, byvoorbeeld dekades lank noue skakeling tussen die Departement en filosowe aan die VU in Amsterdam in Nederland (vgl. bv. Schutte, 2005 en verder 1.6 hieronder). 
Om hierdie ondersoek egter binne die gestelde perke van 'n artikel te hou, word gefokus op die kopstukke (in die sin van die hoofde) van die Departement/Skool gedurende verskillende periodes. Natuurlik het ook ander lede van die Departement bydraes gelewer, maar tot ' $n$ groot mate het die hoofde beleid en praktyk bepaal, waarby hulle eie opleiding 'n belangrike rol gespeel het.

\subsection{Verloop}

In die verkenning word dus kronologies aangetoon wie hierdie figure was, wanneer hulle aan bewind was, waaroor hulle promoveer het en in watter rigting hulle belangstelling en spesialisasie later ontwikkel het.

Klapwijk (1987:99-117) het dit gewaag om van enkele Nederlandse reformatoriese filosowe, wat hy persoonlik meegemaak het, profielsketse te skryf waarin nie net hulle denke nie, maar ook hulle besondere persoonlikhede na vore kom.

Om uit eerlikheid van die dooies sleg te praat (Klapwijk doen dit nie) is onvanpas en om dit van die nog lewendes te doen, is nog minder gewens. Daarom sal die huidige vlieg teen die muur nie hulle karakters beskryf of hulle spesifieke filosofieë evalueer nie, maar sover moontlik saaklik die regimes van die Potchefstroomse kopstukke weergee.

Neutraliteit sal egter nie moontlik wees nie, want aan die een kant stel die vlieg se eie filosofiese oortuigings hom krities in teenoor aksente in die tradisie, en aan die ander kant kan sy liefde vir sy eie denkwyse en aangetrokkenheid tot ' $n$ sekere persoon hom blind maak. ${ }^{1}$

\subsection{Drie hoofperiodes}

Die hele geskiedenis van Filosofie op Potchefstroom soos vergestalt in hierdie handvol filosowe sou in die volgende vier hoofperiodes ingedeel kan word. (1) 'n Periode van wysgerige verkenning (by figure soos F. Postma en S.O. Los); (2) 'n Periode van wysgerige sistematisering (veral by Stoker en later by Taljaard); (3) 'n Periode van wysgerige uitbou (ná Taljaard by verskillende figure); (4) 'n Vierde tyd (vanaf ongeveer 2010) waartydens die vroeëre Christelike benadering geleidelik onder druk begin kom het. Soos genoem, het die verkenning van die eerste periode reeds in hierdie tydskrif verskyn, sodat die volgende drie periodes nou behandel kan word waarvan hierdie een op die sisteembouers gedurende die tweede fase fokus.

\subsection{Die band met Nederland}

Om die meeste filosowe wat hierna ter sprake kom se denke goed te kan verstaan, is kennis van die destydse filosofiese agtergronde in Europa, in besonder Nederland en veral aan die VU in Amsterdam, onontbeerlik. Die filosofiese naelstring tussen die PUK en selfs die latere NWU en die VU is nooit heeltemal deurgeknip nie. Behalwe die vroeëre Los en Postma het vyf van die latere kopstukke byvoorbeeld nagraadse studies aan die VU onderneem.

Teen die begin van die twintigste eeu vind ons die eerste roersele van ' $n$ Christelike benadering tot die filosofie aan die (in 1880 gestigte) VU. Aan die een kant was daar Jan Woltjer (1849-1917) se Logosfilosofie (vgl. Klapwijk, 1980:542-544; Vollenhoven, 2005:441442 en Nijhoff, 2014), wat invloed op Ferdinand Postma (1879-1950) van Potchefstroom se denke gehad het. Aan die ander kant die teoloog, Herman Bavinck (1854-1921), wat sy eie Christelike lewensvisie en Filosofie van die Openbaring ontwikkel het (Bavinck, 1904, 1908, 1979 en Klapwijk, 1980:546-551) waarvoor Sietse Oene Los (1871-1944) op Potchefstroom groot bewondering gehad het. 
Eers aan die begin van die dertigerjare van die vorige eeu ontwikkel twee latere denkers aan die VU 'n meer integrale Christelike filosofie, naamlik Dirk H. Th. Vollenhoven (1892-1978) en Herman Dooyeweerd (1894-1977). Aanvanklik staan hulle wysbegeertes as 'n Calvinistiese Filosofie bekend. Later verkies Vollenhoven egter om sy filosofie liewer 'n Skrifmatige Wysbegeerte te noem, terwyl Dooyeweerd die naam Wysbegeerte van die Wetsidee vir sy filosofie verkies het (vgl. Van der Walt, 2014:47-79 vir meer oor Vollenhoven en 2014:116158 vir meer oor Dooyeweerd). Nog later word die naam 'n Reformatoriese filosofie populêr en tans word eenvoudig van 'n Christelike filosofie gepraat.

Behalwe in Suid-Afrika het hierdie twee patres se denke by verskillende wetenskaplikes in heelwat ander lande invloed gehad (vgl. Van der Walt, 2010).

Met hierdie breë inleiding en agtergrond val die fokus nou op die eerste kopstuk na ongeveer 1917.

\section{H.G. Stoker (04/12/1899-16/05/1993)}

Die vorige verkenning oor filosofie op Potchefstroom 100 jaar gelede (Van der Walt, 2017) het afgesluit met die nog soekende jong Stoker, wat besig is om die boek van S.O. Los oor Logika noukeurig te bestudeer en oral aan die kantlyn notas skryf.

\subsection{Eerste invloede}

Hy lees nie net die Bavinck-dissipel, Los nie, maar ook Bavinck se eie geskrifte (vgl. hierbo asook Bremmer, 1961). Dit spreek hom so aan dat Stoker besluit om onder hierdie Nederlandse teoloog vir sy doktorsgraad te gaan studeer. Dié ideaal kon egter nie realiseer nie omdat Bavinck in 1921 oorlede is.

In Nederland aangekom, vra Stoker van Los en Vollenhoven advies oor 'n ander moontlike promotor. Uiteindelik word dit Max Scheler (1874-1928) hoogleraar te Keulen, Duitsland (Vir meer oor hierdie geskiedenis vgl. Van der Walt, 2014:87 e.v.).

\subsection{Stoker student van Scheler}

Scheler was nie net een van die destydse vooraanstaande Duitse en Europese denkers nie, maar ook'n baie produktiewe skrywer (vgl. Vollenhoven, 2005:368 vir sy belangrikste werke).

Volgens Vollenhoven (2000:245, 247) het Scheler tydens sy lewe verskillende filosofiese konsepsies gehuldig. Die normatiewe rigting van sy filosofie deel egter sy ontwikkelingsgang in twee hoofperiodes in. Aanvanklik (tot 1914) was dit sterk georiënteerd aan die laatrasionalisme, wat groot klem op die metodes van wetenskaplike ondersoek gelê het, in die geval van Scheler op die fenomenologiese metode.

Vanaf ongeveer 1915 word hy die aanhanger van 'n lewensfilosofiese vorm van die irrasionalistiese denke. Aanvanklik toon hy nog openheid vir die Christendom, maar tydens sy laaste lewensfase (1916-1928), toe Stoker onder hom studeer het, sê hy die Christelike geloof vaarwel. ${ }^{2}$

\subsection{Stoker op Potchefstroom}

Die afgestudeerde Stoker (vgl. Stoker, 1925 en 2018), voorheen al dosent in Filosofie en Sielkunde, keer in 1925 terug na die PUK, word later senior lektor, nog later (1930) bevorder tot professor en was daarna lank (1936-1974) hoof van die Departement Wysbegeerte. 
Stoker was nie net die nestor van filosofie op Potchefstroom nie, maar het ook 'n belangrike rol in die breëre geskiedenis van die PUK gespeel (vgl. hoe dikwels hy in Van der Schyff, 2003 genoem word).

\subsection{Belangrikste bydraes}

Stoker het oor die jare vir baie PUK-studente klasgegee, talle ook in hulle M- en D-studies begelei en daarbenewens ook nog talle populêre en wetenskaplike artikels publiseer (vgl. Bingle e.a., 1971:303-311). Sommige van sy geskrifte is byeengebring in Stoker (1967 en 1970).

Miskien sy belangrikste bydrae was dat hy naas die ander twee Nederlandse vaders van 'n Calvinistiese filosofie (Vollenhoven en Dooyeweerd) sy eie Christelike filosofie, die Wysbegeerte van die Skeppingsidee, ontwikkel het (vgl. Stoker, 1970:202-330, ook in 'n Engelse vertaling en elektronies beskikbaar in Stoker, 2007). Daarbenewens was hy die skrywer van Beginsels en metodes in die wetenskap (Stoker 1961), wat jare lank verpligte leesstof vir alle PUK-studente was wat 'n kursus met dieselfde naam moes volg.

Stoker was nie 'n ivoortoringfilosoof nie, maar betrokke in wat rondom hom in sy land gebeur het. As kommandant in die Ossewa Brandwag verset hy hom byvoorbeeld na WOII teen Britse imperiales in SA en word van 1942 vir ' $n$ geruime tyd op Koffiefontein geïnterneer. Soos die meeste van sy tydgenote aan die PUK was hy ook nog 'n voorstander van afsonderlike ontwikkeling vir die verskillende bevolkingsgroepe in Suid-Afrika.

\subsection{Erkenning en waardering}

By sy eie geesgenote het Stoker erkenning geniet. Dit blyk uit die feit dat'n eredogtorsgraad deur die PUK in 1971 aan hom toegeken is, asook die gedenkbundel van dieselfde jaar (Bingle e.a., 1971). Vanaf 1970 was hy ook ereprofessor aan die destydse Randse Afrikaanse Universiteit (tans die Universiteit van Johannesburg).

Dat Stoker se filosofie ook in die buiteland raakgesien is, blyk daaruit dat hy uitgenooi is om in 1963 as gasdosent by die VU op te tree en in 1973 ook by Dordt College en ander Christelike kolleges in die VSA en Kanada.

Omdat Stoker se Christelike benadering tot wetenskap in die algemeen en filosofie in besonder nie sy isolasie van ander denkrigtings impliseer het nie, was daar ook by voorstanders van ander filosofiese strominge in SA en die buiteland waardering vir sy werk. Behalwe dat hy (in 1964) die Stalsprys vir Filosofie van die SA Akademie vir Wetenskap en Kuns ontvang het, blyk dit ook uit diegene wat bydraes tot sy reeds genoemde huldigingsbundel (1971) gemaak het. Van die 22 artikels is, behalwe die 14 deur geesgenote in SA en die buiteland, ook 8 deur filosowe uit verskillende ander filosofiese skole in SA en oorsee gelewer.

\section{6 in Grondliggende onopgeloste probleem}

Stoker en al sy opvolgers as departementshoofde was van oortuiging dat 'n Christelike beoefening van die filosofie en ander wetenskappe alleen moontlik was op die grondslag van geloof in die Skrif. Daarom was die belangrike vraag hoe presies die Woord van God in die wetenskap toegepas moes word. Dit was, 'n probleem wat telkens in die geskiedenis weer opgeduik het en waartoe hierdie reeks meermale sal terugkeer.

\subsubsection{Teologie as die koningin}

In die Gereformeerd-Ortodokse tradisie (ook Gereformeerde Skolastiek genoem) van ongeveer 1570 tot 1930 is die standpunt lank gehuldig dat teologie (van teos=god+logos=wetenskap) die wetenskap is wat God sou bestudeer. (Daarom vroeër ook "Godgeleerdheid" genoem.) Omdat God Homself in die Bybel, 'n heilige Boek, openbaar, sou die teologie wat die Skrifte bestudeer ook vanselfsprekend ' $n$ Christelike karakter dra. 
(Daarom vroeër "Heilige Godgeleerdheid" genoem.) Sulke gedagtes het ook nog 'n rol by Herman Bavinck gespeel.

Volgens Stoker was die teologie ook so 'n soort regina scientiarum (koningin van die wetenskappe) of ten minste die primus inter pares (eerste onder die gelykes), omdat dit die primêre toegang tot God se Woordopenbaring sou wees. Indien die ander dissiplines, filosofie ingesluit, Christelik wou wees, moes hulle dus hulle kennis oor die Bybelse lig by die teologie leen of oorneem.

\subsubsection{Kritiek op Stoker}

Ander Nederlandse voorstanders van 'n Christelike aanpak in die filosofie en ander vakke het in hierdie opsig van Stoker verskil en hom van 'n skolastieke verteologisering van die wetenskap beskuldig (vgl. bv. Malan, 1968 en vir 'n gesprek tussen Vollenhoven en Stoker, vgl. Vollenhoven, 2011:212-214). Volgens Vollenhoven, Dooyeweerd en hulle medestanders kan God nooit die objek van 'n feilbare menslike wetenskap wees nie, maar kan Hy alleen in die geloof geken word. Dit is ook nie die veld van ondersoek (in hierdie geval die Bybel) wat enige wetenskap se Christelike karakter garandeer nie. ('n Marxistiese teologie oor die Bybel is byvoorbeeld ook moontlik.) Die karakter van 'n wetenskap word bepaal deur die (Christelike) uitgangspunt van die wetenskaplike. (Bv. 'n Christelike teologie oor Marxistiese denke.)

'n Christelike beoefening van die ander wetenskappe mag dus nie, soos Stoker wou, van die teologiese wetenskap se feilbare insigte in die Skrif afhanklik gemaak word nie. Elke gelowige wetenskaplike het voorwetenskaplike toegang tot God se Openbaring. Sy kennis van God se Woord stel die denker in staat om aan 'n voorwetenskaplike Christelike lewensvisie gestalte te gee en so 'n werklikheidsvisie lei of bepaal weer sy/haar wetenskaplike werk.

Waarskynlik ook om die beskuldiging te vermy dat hulle filosofieë biblisisme sou impliseer of blote verkapte teologieë was, verwys selfs Vollenhoven in sy Skrifmatige Filosofie nie onnodig na Skrifgedeeltes nie ${ }^{3}$, terwyl Dooyeweerd dit nog minder doen.

Slegs hierdie een vraagstuk is uitgelig, nie alleen omdat dit die hart van ' $\mathrm{n}$ Christelike wetenskapsvisie raak nie, maar ook omdat dit na Stoker telkens weer gedebatteer sou word. Twee uiteenlopende standpunte het na vore gekom. Aan die een kant (by meer teologies georiënteerde dosente) 'n byna biblistiese houding van "wat sê 'n Bybelteks oor dit of dat?" (nog merkbaar by B. Duvenage). Aan die ander kant slegs klem op breëre Skrifperspektiewe soos skepping, sondeval, verlossing en voleinding of die invloed van algemene geloofsuitgangspunte op wetenskaplike werk (opmerklik by die jongere generasie).

Die aandag verskuif nou na die tweede figuur onder die sisteembouers.

\section{J.A.L. Taljaard (29/10/1915 - 23/06/1994)}

Na die aftrede van Stoker in 1964 was Taljaard hoof van die Departement vanaf 1965 tot 1974.

Gegewens oor sy vroeëre lewensgeskiedenis en filosofie is te vinde in die gedenkbundel wat sy studente in 1975 (as 'n spesiale uitgawe van Koers) aan hom opgedra het (Conradie e.a., 1975). Hier volg net enkele momente daaruit. As begaafde kind van 'n groot gesin groei hy 
op gedurende die depressie van die dertigerjare met die begeerte om, soos sy oupa, ook predikant te word.

\subsection{Akademiese vorming op Potchefstroom}

In 1935 het hy genoeg bymekaar geskraap om aan die PUK vir die BA-graad (as voorbereiding vir teologiese studie) in te skryf. As gevolg van finansiële nood kon hy egter net die eerste jaar voltooi en moet in 'n goudmyn gaan werk.

Hy speel intussen ' $n$ leidende rol in die Jongeliedeverenigings op Gereformeerde Grondslag (JV's) en publiseer later ook ' $n$ feesbundel van die Transvaalse Bond van hierdie beweging. Ook die res van sy lewe sou hy besondere belangstelling in die Christelike lewensbeskoulike toerusting van die jeug toon.

Hy raak ook betrokke by die politieke stryd van die Afrikaner teen Engelse oorheersing en as lid van die Ossewa Brandwag staar hy eers die doodstraf in die gesig, maar word vanaf Februarie 1942 tot November 1944 slegs'n politieke gevangene van die destydse regering in ‘n interneringskamp op Koffiefontein. Nogtans ontvang hy van sy medegevangene, Stoker, daar onderrig sodat hy sy tweede jaar BA kon voltooi.

Terug op Potchefstroom voltooi hy sy graadstudies in 1945, word eers junior lektor en later lektor in Psigologie en Filosofie. In die gees van Stoker se denke voltooi hy in twee jaar later sy meestersgraad in Filosofie (Taljaard, 1947).

\subsection{Promosie in Nederland}

In 1948 tree Taljaard in die huwelik met Dirkie van Rooy en in 1950 vertrek hulle na Nederland vir sy doktorsgraadstudie onder prof. Dirk Vollenhoven ${ }^{4}$ aan die VU. Taljaard neem hierdie groot stap ten spyte daarvan dat 'n besoekende Nederlandse teoloog hom gewaarsku het: "Mag die Here jou behoed". Die professor het die destydse onsimpatieke houding van sekere gereformeerde teoloë teenoor ' $n$ reformatoriese filosofie gedeel - 'n Christelike filosofie is as gevaarlik beskou, terwyl die teologie toe nog as iets vanselfsprekend Christelik beskou is (vgl. 2.6 hierbo), die onfeilbare regina scientiarum.

Na die doktorale eksamen promoveer Taljaard met'n proefskrif oor die Duitse filosoof, Franz Brentano (Taljaard, 1955). Brentano (1838-1917) was konsekwent 'n verteenwoordiger van die neo-positivistiese stroming binne die latere rasionalisme. In die loop van sy lewe het hy egter verskillende tipes filosofie voorgestaan. Met sy fenomenologiese metode het hy groot invloed gehad op belangrike denkers soos Husserl (vgl. Vollenhoven, 2005:70).

\section{3 in Navolger van Vollenhoven}

Na sy promosie het Taljaard, geboei deur Vollenhoven se Skrifmatige filosofie, sy jeugskoene in die filosofie van Stoker ontgroei. Hy bied byvoorbeeld die geskiedenis van die Westerse denke aan met behulp van vertalings van Vollenhoven se diktate daaroor (vgl. Taljaard, 1982). Vollenhoven se eie sistematiese filosofie was vir hom radikaler, omdat dit op die Skrif gegrond was sonder om, soos meestal in die teologiese wêreld, biblisties te wees. Christelike filosofie was vir hom meer as 'n wetenskaplike model of 'n teorie, dit was as't ware 'n belydenis van sy geloof. Heelwaarskynlik daarom kon hy soveel invloed op sy studente uitoefen (vgl. 4 hieronder).

Die Vollenhoveniaanse lyn blyk ook nog duidelik uit Taljaard se weergawe van sy eie sistematiese filosofie, soos weergegee in sy Polished lenses (1976). Daarin stel hy hom krities op teenoor byvoorbeeld Stoker en Dooyeweerd. Nogtans was hy geensins ' $n$ blote naprater van sy Hollandse leermeester nie. Alle denkers staan immers tot ' $n$ mindere of meerdere 
mate op die skouers van hulle leermeesters.

\subsection{Belangstellings en kontakte na buite}

Soos reeds geblyk het, het Taljaard 'n besondere belangstelling in die geskiedenis van die Westerse intellektuele denke gehad sowel as in die formulering van ' $n$ eie Christelike standpunt. Daarbenewens het hy ook in die antropologie, espistemologie, samelewingsfilosofie, opvoedingsfilosofie, etiek en estetika belang gestel en daaroor gepubliseer (vgl. Conradie e.a., 1975)..

Hy was altyd nou betrokke by wat in die Afrikaanse samelewing en kultuur gebeur het en heelwaarskynlik ook nog 'n voorstander van die destydse apartheidsbeleid van die NP. regering.

Net soos Stoker het ook Taljaard nie sy denke in "splendid isolation" onwikkel nie. Hy was byvoorbeeld voorsitter (vanaf 1972 tot 1975) van die Filosofiese Vereniging van SA waarvan voëls van verskillende filosofiese vere lede was. Anders as wat 'n mens van sy antisintetiese filosofie sou verwag (nie met Kuyperiaanse antitese te verwar nie), het hy graag in gesprek getree met byvoorbeeld eksistensialiste, fenomenoloë, taalanalitiese wysgere en ander wetenskaplikes.

\section{4. in Terugblik}

Terugskouend op die nalatenskap van Stoker en Taljaard, word hier nie hulle filosofiese bydraes en onderlinge verskille evalueer nie, aangesien die skrywer dit reeds elders gedoen het (Van der Walt, 2014a en 2014b). Daar word slegs op die gemeenskaplike religieuse vertrekpunt van hulle denke gefokus. Hulle was integrale gelowige, roepingsbewuste hervormers en stryders wat destyds 'n lewensbeskoulik-filosofiese ark of toevlugsoord vir soekende adolessente studente gebied het.

Indien hierdie tipering die indruk sou skep dat daarmee hierdie twee mensekinders opgehemel word, omdat dit vir hulle moontlik was om met hulle denkwerk die paradys op die hoëveldse Bult te laat neerdaal, sou dit'n heeltemal verkeerde gevolgtrekking wees (vgl. die breedvoeriger evaluering van hierdie tradisie aan die einde van die volgende artikel). Terselfdertyd mag die waardering wat hulle toekom, ook nie nagelaat word nie.

\subsection{Oortuigde Christene}

Filosofie was op die keper beskou nie nommer 1 vir hulle lewe nie. In die eerste plek was hulle gelowige Christene wat kinderlik op God en sy Woord vertrou het (Matt. 18:3). As filosowe het hulle hul ook nie daaroor geskaam nie, maar openlik erken dat dit die diepste wortel (radix) van hulle denke was en dat hulle vanuit dié wortel wou dink.

Hiermee het hulle'n eeu-oue Christelike tradisie gesteun waarvan byvoorbeeld die kerkvader, Augustinus (354-430), 'n verteenwoordiger was met sy uitspraak credo ut intelligam, ek glo, sodat ek kan weet.

By die stigtingsvergadering (op 01/01/1936) van die Vereniging voor Calvinistische Wijsbegeerte in Nederland het Vollenhoven dit ook benadruk dat ' $\mathrm{n}$ in Christo philosophari slegs die gevolg is van die oortuiging dat religie 'n saak van die hart is wat jou hele lewe bepaal. Voor, agter, anderkant en bokant 'n feilbare Christelike filosofie staan God se onfeilbare Woord wat die grense van alle menslike insig oorskry.

Stoker en Taljaard was, behalwe oortuigde Christene, gevolglik ook figure wat integraalChristelik wou filosofeer. Die Latynse woord integer beteken "heel". Hulle integriteit het daarin bestaan dat hulle sonder huiwering ' $n$ religieuse kompas gevolg het in diens van die koninkryk van God. Hulle was nie gesplete, skisofrene Christene, wat 'n sogenaamde neutrale filosofie daar probeer stel het wat waterdig van hulle Christelike geloof geskei is 
nie. Vergelyk die subtitel van Taljaard se hoofwerk van 1976: Polished lenses; a philosophy that proclaims the sovereignty of God over creation and also over every aspect of human activity. ${ }^{5}$

\subsection{Gehoorsame roepingsbewustes}

'n Volgende kenmerk van Stoker en Taljaard, wat nou met die vorige saamhang, was hulle gehoorsame, toegewyde roepingsbewustheid. Hulle filosofieë is gebore en het ontwikkel as gehoorsame antwoord op God se fundamentele liefdesgebod (Matt. 22:37): liefde tot God met jou hele hart en hele lewe, jou verstand ingesluit! Hulle begeerte na wysheid (wysbegeerte) en liefde vir die wysheid (filosofie) was gegrond in hul liefde vir God en hulle naaste.

In hierdie "liefhê met die verstand" was die verstand egter vir hulle nie die ongeskonde, outonome verstand, die Rede van die rasionalistiese Westerse denke, wat sy eie wette vir die lewe sou kon voortspin nie. Hulle het erken dat ook hulle verstandelike liefdesaktiwiteit voortdurend getoets moet word by die lig van God se openbaring en vernuwe moes word deur die krag van die Heilige Gees.

Hulle filosofieë het, ten spyte van gebroke, nie gerus op die kussing van 'n vergoddelikte menslike Rede of op irrasionalistiese postmodernistiese paradigmas nie, maar op eenvoudige geloof in God se ryk openbaring in die skepping, in die Skrifte en in Christus. Daarom was hul filosofie ook vir hulle 'n roeping en 'n belydenis op wetenskaplike gebied.

Wanneer dit gebeur, kan 'n mens ten spyte van jou eie swakheid sterk wees (vgl. 2 Kor. 12:10) omdat jy jou vertroue stel op God en sy Beloftewoord. Dan kan 'n mens ook seker weet dat jou arbeid - self iets soos die nooit voltooide soeke na wysheid - nie tevergeefs sal wees nie en 'n mens daarom ook standvastig, onwankelbaar daarmee kan volhard (1 Kor. 15:58).

So ' $n$ instelling impliseer dus nie ' $n$ swakheid wat eenvoudig as goed en reg alles aanvaar wat op die filosofiese mark aangebied word nie. Daarom kon Stoker en Taljaard, behalwe integrale gelowiges en gehoorsame roepingsbewustes, ook hervormers wees.

\subsection{Hervormers}

Twee kortgeboude manne, nietige mensies. En tog kon hulle ' $n$ hervormde filosofie daarstel en selfs hervormers genoem word. Hierbo het dit alreeds geblyk uit die feit dat hulle eeuoue sintetiese en dualistiese "Christelike" filosofieë probeer vervang het met die integrale lewensuitkyk van 'n reformatoriese filosofie.

"Reformatories" het vir hulle nie slegs ingehou dat dit 'n integraal-denkende Christen moet wees wat filosofeer nie. Die resultaat daarvan moes ook 'n Christelike karakter openbaar. "Reformatories" het vir hulle ook nie konserwatiewe repristinasie beteken nie, maar om op die voorpunt van die tye te probeer beweeg. Verder het "reformatories" vir hulle gehoorsaamheid aan die Openbaring van God beteken sonder om in statiesfundamentalistiese biblisisme te verval.

Hulle het in die lig van Bo belangrike dinge raakgesien wat ander denkers ontglip het. So, byvoorbeeld dat daar ' $n$ God is wat as Skepper hierdie werklikheid tot stand gebring het, dat Hy verder duidelike wette vir sy skepping en riglyne vir mens gestel het. Dat sonde, uit ongehoorsaamheid aan God se verordeninge gebore, diep, peillose gevolge inhou - ook vir die mens se denke. Dat amnestie in Christus moontlik is. Dat gelowiges 'n roeping Pro Rege (vir hul Koning) het op elke lewensterrein. Dat neutraliteit - ook op wetenskaplike terrein -

5 Soos hierbo (by 2.6) verduidelik, het Stoker egter tot ' $n$ mate nog gepoog om teologiese perspektiewe in sy Christelike filosofie te integreer. Van Belle $(2018: 93,94)$ lewer skerp kritiek op allerlei sulke metodes om geloof en wetenskap, teologie en ander wetenskappe te integreer. Volgens Van Belle gaan sulke pogings uit van' $n$ dualistiesde visie tussen twee relata wat saamgevoeg moet word en kan dit dus nie as integrale Christelike denke beskou word nie. 
'n droom is. Die kern van Stoker en Taljaard se religieus-begronde denke was die basiese, eenvoudige Bybelse boodskap.

\subsection{Stryders}

Met so 'n radikaal-integrale vertrekpunt kan 'n mens verwag dat jy onder die spervuur sal beland van arrogante rasionaliste, irrasionalistiese soekers, dikdoenerige wetenskaplikes en ander geïrriteerdes wat in die mou lag oor jou naïwiteit", "fundamentalisme" of "fideïsme" om nog in 'n God en sy openbaring te glo.

Was daar nie soms tog die versoeking by hierdie twee manne om maar te aanvaar wat vooraanstaande denkers van hulle tyd geleer het nie? Hoe het hulle staande gebly teen die verleiding om populêr en aanvaarbaar te wees?

Soos sedert antieke tye moes Stoker en Taljaard se filosofiese voorgangers en tydgenote ook met die basiese lewensvrae stoei en daarop hul antwoorde gegee het. Een van hierdie vrae was of God of 'n god wel bestaan en wat sy rol sou wees. Hier volg net enkele antwoorde uit die geskiedenis.

Gedurende die antieke Griekse denke en later ook in die Middeleeue is nog probeer om die bestaan van God redelik te bewys - God was die eindpunt van die menslike intellek. Later (bv. by Kant) is 'n godsidee nog nodig geag, want dit sou darem 'n steunpunt bied vir menslike moraliteit. Nog later (vir bv. Schleiermacher) is godsdiens nog slegs as oneindigkosmiese menslike gevoel beskou.

Feuerbach gaan nog verder: die Christelike religie is niks anders nie as'n projeksie van menslike behoeftes na iets groter as die mens. Marx noem dit openlik opium, 'n verdowingsmiddel, terwyl Freud dit as 'n illusie, 'n wensdroom, 'n neurotiese stoornis beskou het.

Alleen weens die diep religieuse wortels van hulle filosofie, vaster as hulle eie filosofie, kon hierdie twee Potchefstroomse denkers staande bly teen sulke verleidelike dwalinge. In die helder son van God se openbaring verskrompel die vyeblare van al bogenoemde godsidees, wêreldvisies en mensbeskouings.

\subsection{Arkbouers}

Op droë grond en dalk onder 'n wolkelose hemel is Noag - al vir jare lank - besig om 'n tamaaie skip te bou (Gen. 6:5 e.v.). Het sy toeskouers en selfs medewerkers nie dalk kopskuddend gedink hy is van sy lot getik, heeltemal gek nie, begin lag en selfs met hom die spot gedryf nie?

Hy gaan egter elke dag ongestoord met sy moeitevolle werk voort. Waarom? Omdat dit ' $n$ opdrag van God self was. Hy kon dus daarvan seker wees dat hy nie met iets sinloos besig was nie. En sy absolute vertroue was nie tevergeefs nie. Terwyl sy ongelowige spotters die een na die ander onder die water verdwyn, red hy mens en dier.

Stoker en Taljaard was ten slotte ook die bouers van 'n veilige lewensbeskoulike ark vir soekende jong Christelike studente. Sestig jaar gelede (vanaf 1958) was dit die diep religieuse wortels van hierdie twee dosente se filosofie en nie die details daarvan nie wat hierdie vlieg ook "gehook" het.

En hy is nog steeds daarvan oortuig dat 'n integrale Christelike lewensvisie en ' $n$ filosofie daarop gebou - ten spyte van al die gebreke wat dit mag bevat - vandag nog 'n reddingsboei, 'n toevlugsoord vir ons jeug kan wees terwyl die vloedwaters van sekularisme rondom hulle al hoër styg en hulle in postmodernistiese relativisme verswelg word. (Word vervolg) 


\section{BIBLIOGRAFIE}

Bartholomew, C. \& Goheen, M. 2013. Christian Philosophy; a systematic and narrative introduction. Grand Rapids, Michigan: Eerdmans.

Bavinck, H. 1904. Christelijke wereldbeschouwing. Kampen: Kok.

Bavinck, H. 1908. Wijsbegeerte der Openbaring; Stone-lezingen voor het jaar 1908, gehouden te Princeton, N.J. Kampen: Kok.

Bavinck, H. 1979. The philosophy of revelation. Grand Rapids, Michigan: Baker Book House.

Bingle, H.J.J., Du Plessis, P.G.W., Duvenage, B. \& Van der Merwe, N.T., (reds). 1971. Truth and reality; philosophical perspectives on reality dedicated to prof. dr. H.G. Stoker. Braamfontein: De Jong's Bookshop.

Bremmer, R.H. 1961. Bavinck als dogmaticus. Kampen: Kok.

Bril, K.A., Hart, H. \& Klapwijk, J., (reds). 1973. The idea of Christian Philosophy; essays in honour of D.H.Th. Vollenhoven. Special edition of Philosophia Reformata, 38;1-234.

Conradie, H., Van der Merwe, N.T., Van der Walt, B.J. \& Van Jaarsveld, B.J., (reds). 1975. Social theory and practice: crosscuts and perspectives. Philosophical essays in honour of prof. J.A.L. Taljaard. Special issue of Koers, 40(4-6). https://doi.org/10.4102/koers.v40i4-6.833

De Gaay Fortman, W.E., (ed). 1965. Philosophy and Christianity; philosophical essays dedicated to Prof Dr Herman Dooyeweerd. Kampen: Kok.

Duvenage, P. 2015. Afrikaanse filosofie. Bloemfontein: Sun Press.

Hengstmengel, B. 2015. Denken met het hart; Christelijke filosofie in de traditie van Augustinus en Calvijn. Amsterdam: Buijten \& Schipperheijn.

Heyns, M. \& Hoogstad, H., (eds). 2010. Wetenskap in die lig van die Môrester/Scholarship in the light of the Morningstar: artikels opgedra/essays dedicated to Barend Johannes (Bennie) van der Walt. Special issue of Koers, 75(1).

Klapwijk, J. 1980. Honderdjaar filosofie aan de Vrije Universiteit. In Van Os, M. \& Wieringa, W.J., (reds). Wetenschap en rekenschap 1880-1980; een eeuw wetenshapsbeschouwing aan de Vrije Universiteit. Kampen: Kok. pp. 529-593.

Klapwijk, J. 1987. Kijken naar kopstukken. Amsterdam: Buijten \& Schipperheijn.

Malan, D.J. 1968. 'n Kritiese studie van die wysbegeerte van H.G. Stoker vanuit die standpunt van H. Dooyeweerd. Amsterdam: Buijten \& Schipperheijn. https://doi.org/10.1163/22116117-90001214

Nijhoff, R.A. 2014. De logosfilosofie van Jan Woltjer (1849-1917); logos en wijsbegeerte aan de vroege Vrije Universiteit. Amsterdam: Buijten \& Schipperheijn.

Schutte, G. 2005. De Vrije Universiteit en Zuid-Afrika (2 dele). Zoetemeer: Uitgeverij Meinema.

Stellingwerff, J. 1992. D.H.Th. Vollenhoven (1892-1978); reformator der wijsbegeerte. Baarn: Ten Have.

Stellingwerff, J. 2006. Geschiedenis van de reformatorische wijsbegeerte; een Christelijk perspectief. Sonder plek: Stichting voor Reformatorische Wijsbegeerte.

Stoker, H.G. 1925. Das Gewissen; Erscheinungformen und Theorien. Bonn: Friedrich Cohen.

Stoker, H.G. 1961. Beginsels in metodes in die wetenskap. Potchefstroom: Pro Rege Pers. (In 1969 herdruk in Braamfontein deur Boekhandel De Jong.) https://doi.org/10.1163/22116117-90001089

Stoker, H.G.1967. Oorsprong en rigting. (Deel 1.) Kaapstad: Tafelberg. https://doi.org/10.1163/2211611790001195

Stoker, H.G. 1970. Oorsprong en rigting. (Deel 2.) Kaapstad: Tafelberg.

Stoker, H.G. 2007. Uit, deur en tot God is alle dinge: werke van prof. H.G. Stoker. Bloemfontein: VCHO (CD Rom) en ook by http://www.vcho.za/publikasies/akademiese-publikasies-van-hg-stoker.php (Datum van toegang Desember 2017.)

Stoker, H.G. 2018. Conscience; phenomena and theory. (Translated by P.E. Blossen). Notre Dame: Notre Dame University Press.

Taljaard, J.A.L. 1947. 'n Kritiese studie van die waarde in die beskouinge van B. Bosanquet, W. Stern \& P.B. Perry. Potchefstroom: PU vir CHO. (M.A. Verhandeling.)

Taljaard, J.A.L. 1955. Franz Brentano as wijsgeer; 'n bydrae tot die kennis van die neo-positivisme. Franeker: T. Wever. 
Taljaard, J.A.L. 1976. Polished lenses; a philosophy that proclaims the sovereignity of God over creation and also over every aspect of human activity. Potchefstroom: Pro Rege Press.

Taljaard, J.A.L. 1982. Kort oorsig van die geskiedenis van die Wysbegeerte. Potchefstroom: PU vir CHO. (Diktaat 5/82.)

Tol, A. 2010. Philosophy in the making; D.H.Th. Vollenhoven and the emergence of Reformed Philosophy. Sioux Center, lowa: Dordt College Press.

Van Belle, H.A. 2018. Coram Deo; living life in the presence of God in a secular age. (Unpublished manuscript.)

Van der Schyff, P.F. 2003. Wonderdaad! Die PUK tot 1951: wording, vestiging en selfstandigheid. Potchefstroom: $\mathrm{PU}$ vir $\mathrm{CHO}$.

Van der Walt, B.J. 2010. An overview of the global presence of a Christian Reformational philosophy and scholarship. In Van der Walt, B.J. At home in God's world. Potchefstroom: The Institute for Contemporary Christianity in Africa. pp. 127-151.

Van der Walt, B.J. 2014a. At the cradle of a Christian philosophy in Calvin, Vollenhoven, Stoker and Dooyeweerd. Potchefstroom: The Institute for Contemporary Christianity in Africa.

Van der Walt, B.J. 2014b. Constancy and change; historical types and trends in the passion of the Western mind. Potchefstroom: The Institute for Contemporary Christianity in Africa.

Van der Walt, B.J. 2017. Op die spore van filosofiese onderwys op Potchefstroom honderd jaar gelede. Koers, 82(1) Elektronies beskikbaar. https://doi.org/10.19108/koers.82.1.2287

Van Dijk, W.K. \& Stellingwerff, J., (reds). 1961. Perspectief; feestbundel van de jongeren bij het vijfentwintig jarig bestaan van de Vereniging voor Calvinistische Wijsbegeerte. Kampan: Kok.

Van Eeden, E.S., (red). 2005. "In U lig"; die PU vir CHO van selfstandigwording tot samesmelting. Potchefstroom: Noordwes-Universiteit (Potchefstroomkampus).

Verburg, M.E. 1989. Herman Dooyeweerd: leven en werk. Baarn: Ten Have.

Vollenhoven, D.H.Th. 1933. Het Calvinisme en de Reformatie van de Wijsbegeerte. Amsterdam: H.J. Paris.

Vollenhoven, D.H.Th. 2000. Schematische Kaarten; filosofische concepties in probleemhistorisch verband. (Reds. K.A. Bril \& P.J. Boonstra). Amstelveen: De Zaak Haes.

Vollenhoven, D.H.Th. 2005. Wijsgerig Woordenboek.(red. K.A. Bril). Amstelveen: De Zaak Haes.

Vollenhoven, D.H.Th. 2011. Wijsbegeerte en theologie. In Vollenhoven Gastcolleges Wijsbegeerte. (Reds. K.A. Bril \& R.A. Nijhoff). Amstelveen: De Zaak Haes. pp. 201-214.

Woldring, H.E.S. 2013. Een handvol filosofen; geschiedenis van de filosofiebeoefening aan de Vrije Universiteit van 1880 tot 2012. Hilversum: Verloren.

Zijlstra, B. 1975. Introduction. In Kalsbeek, L. Contours of a Christian Philosophy. Toronto: Wedge Publ. Foundation. pp. 14-33. 